\title{
Omaehtoinen ryhmäopiskelu ja ammatillinen kehittyminen
}

TAINATUOMI

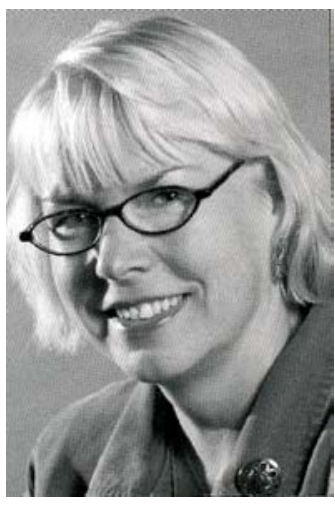

Taina Tuomi pohtii väitöstutkimuksessaan omaehtoisen ryhmäopiskelun merkitystä ammatillisessa kasvussa sekä sitä, miten ammattiliiton osoittama ryhmäopiskelun tuki, jonka tavoitteena on kannustaa työntekijöitä kyseenalaistamaan ja uudelleen arvioimaan ajattelu- ja toimintatapojaan, auttaa vahvistamaan heidän ammatillista osaamista ja aktiivista osallisuutta omaan edunvalvontaan. Tutkimuksen taustalla on vuosina 1995-1996 Kunta-alan ammattiliitossa KTV:ssä toteutettu täydennyskoulutuksen kokeilu.
Op pintokerho-opiskelu on merkittävä osa vapaata sivistystyötä ja pohjoismaista aikuiskoulutusperinnettä. Kunta-alan ammattiliiton jäsenen keskuudessa sitä on käytetty 1980-luvun puolivälistä lähtien myös ammatillisen kehittymisen väylänä. Täydennyskoulutuksen kokeilussa kolmetoista opintoryhmää opiskeli omaehtoisesti ammattiaan tai työtään käsitteleviä aiheita. Ryhmät siis määrittivät itse oppimistarpeensa ja-tavoitteensa, valitsivat opiskeluaiheen sekä sopivat opiskelumetodit. Useimmilla ryhmillä oli työnantajan lupa opiskella työaikana ja työpaikalla. Ryhmät muodostuivat pääasiassa saman ammattialan tai työpaikan kuntatyöntekijöistä: mielenterveyshoitajista, kehitysvammaisten hoitajista, päivähoitajista, toimistotyöntekijöistä, pesulatyöntekijöistä. sairaala-apulaisista, maatalouslomittajista, siivoojista, ruokapalvelutyöntekijöistä, perhepäivähoitajista, vanhainkodin työntekijöistä ja kodinhoitajista.

Kunta-alan ammattiliitto tarjosi kokeilussa opintokerhojen ulkopuoliseksi tukijaksi tukihenkilön. Kokeilun vastuullisena henkilönä olin samalla kaikkien ryhmien tukihenkilö. Tehtäväni ei ollut toimia opetuksen sisällöllisenä asiantuntijana ryhmässä, vaan antaa omia ehdotuksiani opiskeluprosessiin etenemiseen, kannustaa tarkastelemaan kriittisesti ja arvioimaan uudelleen omia ja muiden ajattelu- ja toimintatapoja, auttaa luomaan keskusteluyhteyksiä työyhteisössä sekä auttaa arvioimaan oppimisen tuloksia. Mezirowin $(1991 a, 11)$ mukaan oppimista syntyy, kun tietyn kokemuksen merkitys tulkitaan uudelleen tai tätä tulkintaa tarkistetaan siten, että uusi syntynyt tulkita ohjaa myöhempää ymmärtämistä, arvottamista ja toimintaa. Oppimisessa tieto ei yksin riitä. Tarvitaan myös ajattelemisen kykyä: kykyä tutkia, ymmärtää, kyseenalaistaa ja tulkita asioita.

Toimintatapani tukihenkilönä pohjautui Mezirowin (1991b, 211-212) käsityksiin aikuiskouluttajan tehtävistä transformatiivisessa oppimisessa sekä joiltain osin saksalaisen Oskar Negtin (1971, 55-56; 1976, 362-363) kouluttajan tehtävien määrittelyyn saksalaisen ay-koulutuksen kehittämisessä.

\section{Ryhmäoppimispäiväkirja kriittisyyden edistäjänä}

Yhteydenpito opintoryhmän ja minun välillä tapahtui pääasiassa ryhmän yhteisesti kirjoittaman oppimispäiväkirjan ja tukihenkilönä siihen laatimani kommenttikirjeen avulla. Ryhmänjäsenet kirjoittivat kokoontumisistaan vuorotellen ryhmäoppimispäiväkirjaa. Kokoontumisensajälkeen 
he lähettivät sen minulle, johon kirjoitin omat kommenttini. Ryhmäoppimispäiväkirjan tarkoituksena oli antaa ryhmälle väline, jossa se voisi reflektoida käytyä keskustelua ja oppimaansa, ja joka samalla antaisi ryhmän ulkopuoliselle tukijalle mahdollisuuden päästä siinä määrin ryhmän keskusteluun sisälle, että hän voisi esittää omia huomioitaan opiskelun edistämiseksi. Lähtökohtana kokeilussa oli, että ryhmä kokoontumisensa aluksi kävisi yhdessä läpi edellisen kerran päiväkirjan ja minun siihen lähettämät kommentit. Ryhmä itse sai päättää, miten antoi niiden ohjata opiskeluaan.

Vaikka päiväkirjan pitäminen on vanha itseilmaisun ja itsereflektion muoto, ei ryhmäoppimispäiväkirjan käytöstä ole aikaisempia tutkimuksia Suomessa. Graybealin (1987, 307-310) mukaan ryhmäoppimispäiväkirja integroi kurssimateriaalin, inmettelyn ja eri inmisten ajatusten ja "energian" auttaen opiskelijoita liittämään opitut käsitteet ja termit omiin kokemuksiinsa. Hänen kokemustensa mukaan yhteinen päiväkirja auttaa myös rakentamaan yhteisöllisyyttä. Bruneriin, Vygotskyyn, Emigiin, Brittoniin ja Moffetiin viitaten Macrorie $(1987,1)$ muistuttaa, että ihminen löytää merkityksiä maailmassa tutkimalla sitä oman luontevan puhekielen kautta. Lukeminen, kirjoittaminen, puhuminen ja kuunteleminen auttavat jokainen erityisellä tavalla tarkastelemaan ja ymmärtämään opiskeltavaa asiaa. Ihmisen välittäessä siitä, mitä kirjoittaa ja näkiessään siinä yhteyksiä omaan elämäänsä hän sekä oppii että kirjoittaa paremmin. PISA-tutkimuksen arvioinneissa Literacy Skills for the World of Tomorrow (OECD, 2003, 8) todetaan, että: "(N)e, jotka todennäköisimmin muistavat informaation, eivät aina saavuta parhaita tuloksia, kun taas ne, jotka prosessoivat tai työstävät opittavaa, onnistuvat hyvin."

Tutkimukseni osoitti, että omaehtoisessa ryhmäopiskelussa ryhmäoppimispäiväkirja auttaa poistamaan kynnystä uskallukseen reflektoida kirjoittaen ja alistaa se myös muiden arvioitavaksi. Omaehtoiset ryhmät näyttävät kuitenkin tarvitsevan ohjausta reflektiiviseen kirjoittamiseen sekä tukihenkilön, joka antaa palautetta kirjoittamisesta ja oppimisesta. Kokeilussa päiväkirjan kirjoittamista näytti helpottaneen se, jos ryhmän jäsenet olivat tottuneita kirjoittajia ja joutuivat esimerkiksi työssään kirjoittamaan raportteja. Lähes jokaisesta ryhmästä nousi kuitenkin arviointikeskustelussa esille kirjoittamisen vaikeu- det. Tällaisina pidettiin oman kirjoitustaidon heikkenemistä, päiväkirjaan kirjoitettujen asioiden yksityisyyden suojan pelkoa sekä vaikeutta poimia päiväkirjaan olennaiset asiat keskusteluista. Tästä huolimatta ryhmäoppimispäiväkirjaa pidettiin myönteisenä kokemuksena. Sen koettiin ryhdittäneen opiskelua, toimineen opiskelun kertauksen välineenä ja kasvattaneen ryhmässä yhteisöllisyyden tunnetta. Lisäksi se antoi mahdollisuuden saada ulkopuoliselta jatkuvaa palautetta oppimisesta.

Siitä huolimatta, että keskustelu ryhmässä oli kriittisesti reflektoivaa, ei se välttämättä siirtynyt päiväkirjaan. Kirjoittajalle oppimispäiväkirjan kirjoittaminen asettaa vaatimuksia sekä kielelliseen että kirjoitustaidon hallintaan. Kirjoittajan, samoin kuin koko ryhmän, on myös ymmärrettävä päiväkirjan käytön merkitys, jotta kirjoittaminen koetaan mielekkääksi.

Oppimispäiväkirjojen kirjoittamisen ongelmat, samoin kuin päiväkirjojen kirjoittamisen tapa nostavat esille tarpeen kiinnittää enemmän huomiota aikuisten luku- ja kirjoitustaitoihin sekä kykyyn ilmaista ajatuksiaan kirjoittaen. Lukutaitoa ja tietotyöntekijöiden kvalifikaatioita käsittelevissä vertailuissa ja tutkimuksissa (ks. Linnakylä et. al. 2000; Blom et. al. 2001, 220; Suomi (o)saa lukea 2000, 10 ja 44; Lash 1995, 183) pidetään aikuisten monimedialukutaidon parantamista eli kykyä kirjoittaa, ymmärtää ja tuottaa tekstiä tärkeänä tekijänä tietoyhteiskunnassa. Niiden mukaan tietoteknisten valmiuksien puute ja heikko lukutaito voivat muodostua yhdeksi syrjäytymisen tekijäksi. Asioiden hoidon ja palvelujen siirtyessä yhä enemmän tietotekniikan välillä tapahtuvaksi saattavat puutteelliset taidot rajoittaa paitsi ammatinvalinta ja -vaihtoa sekä työnsaantia mutta myös yhteiskunnallista osallistumista ja kansalaisena toimimista .

Tietoyhteiskunnan työtehtäville on tyypillistä tiedonhankintaan, tiedonvälittämiseen, ongelmanratkaisuun, kommunikointiin ja yhteistyötaitoihin liittyvä osaaminen. Yhä useamman ammatin työtehtävät sisältävät erilaisia luku-, kirjoitus- ja laskutehtäviä, esimerkiksi raportteja, kirjeitä, suunnitelmia, ohjeita, laskuja, muistioita. Samoin työn organisointi työryhmiin, verkostoihin, tiimeihin, projekteihin edellyttää työhön liittyvän tiedon välittymistä myös näitä laajemmille tahoille. Monimedialukutaidon kehittämisen haaste on suuri erityisesti niille ikääntyneille työntekijöille, joiden päivittäiseen työhön ei ole 
aiemmin sisältynyt tekstin tuottamista ja joilla ei ole tosiasiallisesti mahdollisuutta käyttää tietokonetta työssään. Käytännössä tämä tarkoittaa muun muassa suurta osaa kuntien peruspalvelutehtävissä toimivista (esim. Berndtson 2002).

\section{Oppiminen omaehtoisessa ryhmässä}

Tutkimukseni tulokset vahvistivat, että myös omaehtoinen ryhmäopiskelu voi toimia ammatillisen kehittymisen väylänä. Ryhmien kuvaukset oppimisesta kertoivat ryhmien jäsenten havaitsemistapojen muutoksesta, johon sisältyi reflektiivistä toimintaa. Oppiminen jäsentyi viiteen tasoon: 1) opiskeltavan ilmiön tunnistamiseen omassa toimintaympäristössä, 2) tiedon aktiiviseen käyttämiseen työssä, 3) nykyisten toimintatapojen perustelemiseen, 4) toimintatapojen kyseenalaistamiseen sekä 5) omien ajattelu- ja toimintatapojen muuttamiseen. Kaikkiin oppimisen tasoihin sisältyi toiminnallista muutosta, mikä ei välttämättä ollut näkyvää. Oppiminen kuvattiin muun muassa omana aktivoitumisena osallistua keskusteluihin ja käynnistää niitä, tarkkailun lisääntymisenä, tilanteiden harkinnan ja ennakoinnin lisääntymistä ja perusteltuna toimimatta jättämisenä.

Ryhmäopiskelussa dialogi nousee toisenlaiseen merkitykseen kuin normaalissa yksinopiskelussa. Koska ryhmässä ei ole asiantuntijaa opettamassa opiskeltavaa aihetta, on ryhmän itse perehdyttävä aiheeseen valitsemansa oppimismateriaalin avulla. Omaehtoinen ryhmäopiskelu perustuukin jäsenten tasavertaisuuteen ja samanarvoisuuteen vertaisryhmässä. Tutkimuksen mukaan tämä rohkaisi omien ajatusten ja "tyhmiltäkin tuntuvien kysymysten" esittämistä.

Ryhmäopiskelu mahdollisti omien dialogitaitojen kehittämisen, kuten kuuntelemisen, mielipiteiden selkiyttämisen, omien kokemusten hyödyntämisen sekä asian tarkastelun toisen silmin. Dialogi kasvatti yksilöitä itseään ja vahvisti sosiaalisuutta yhteisössä. Yhteenkuuluvuus ei syntynyt vain siitä, että kuuluttiin samaan ryhmään, vaan myös siitä, että koettiin saaneen joitain erityistä aikaiseksi yhdessä. Monille, erityisesti yksintyöskentelijöille ja kovan paineen alla työskenteleville ryhmä toimi myös paikkana, jossa ylipäätään sai mahdollisuuden keskustella työhön liittyvistä asioista toisten kanssa.

Kyky harjoittaa dialogia muuttuu yhä merkityksellisemmäksi työelämässä. Nykypäivän muuttuva ja kompleksinen työelämä on täynnä tilanteita, joissa osallistujilta odotetaan yhteistyötä ja asioiden yhteistä käsittelyä ja ideointia muiden kanssa. Yhä useammin työtä tehdään tiimeissä, verkostoissa, projekteissa. Siten ryhmäopiskelussa opitut dialogiset ja yhteistyötaidot valmentavat myös uusiin työn organisoinnin muotoihin.

Opintoryhmä korostui myös tärkeänä muutokseen valmistautumisen paikkana. Ryhmissä oli mahdollisuus nostaa esille muutostilanteisiin liittyviä epävarmuutta synnyttäviä tekijöitä ja selvittää niitä yhdessä. Pelkkä tieto tulevista muutoksista ei riitä, vaan osallistujat halusivat avointa keskustelua päättäjien ja esimiesten kanssa ja osallistua erilaisten vaihtoehtojen punnitsemiseen. Ryhmät järjestivätkin itse keskustelutilaisuuksia niin kunnallisten päättäjien kuin valmistelevien virkamiesten ja lähiesimiesten kanssa epäselvistä kysymyksistä. Keskustelutilanteisiin valmistautuminen ja itse keskustelut auttoivat ryhmän jäseniä käsittelemään omia olettamuksiaan etäämmältä ja ymmärtämään niiden yhteiskunnallista kytkentää. Siten niillä oli emansipoiva, vapauttava merkitys ryhmien jäsenille.

\section{Esimiehen merkitys oppimisen hyö- dyntämisessä}

Mezirow (1991c, 354-355) näkee, että reflektiivistä diskurssia seuraavat oivallukset eivät itsessään johda uudistavaan oppimiseen, vaan tarvitaan tahtoa toimia uusien vakaumustensa mukaisesti. Opintoryhmien jäsenillä näytti olleen tahtoa oppimisen hyödyntämiseen, mutta toiminta saattoi estyä työyhteisössä. Ryhmien jäsenten kuvaukset oppimisesta välittivät paljon sellaista oppimista, minkä hyödyntäminen riippuu opiskelijasta itsestään, esimerkiksi tarkkaavaisuuden lisääntyminen tai toimintatapojen perusteleminen itselleen tai niiden kyseenalaistaminen. Silti omaehtoisen ryhmäopiskelun avulla näyttää olevan vaikea saavuttaa sellaisia toiminnallisia muutoksia työpaikalla tai omassa työssä, joista päätöksen tekee jokin muu taho kuin työntekijä itse. Päinvastoin ryhmäopiskelun vaikutukset saattoivat johtaa jopa ristiriitoihin työpaikalla muiden ammattiryhmien kanssa. Tämä näyttäytyi muun muassa tehtäväkuvien muutoksina.

Opintoryhmien saama lupa kokoontua työajalla ja työpaikalla antoi positiivisen kuvan osallistujien esimiesten suhtautumisesta omaehtoiseen 
opiskeluun. Kuva heikkeni opiskelun aikana, koska osallistujat joutuivat itse ratkaisemaan sijaisjärjestelyt opiskelunsa ajaksi. Esimiehet eivät myöskään olleet aloitteellisia opiskeluaiheen ja oppimisen tulosten käsittelyssä työpaikalla. Pyytäessään ryhmien jäsenet saivat siihen tilaisuuden esimerkiksi työpaikkakokousten yhteydessä. Esimiehet eivät kuitenkaan systemaattisesti arvioineet sitä, millä tavoin ryhmässä hankittua osaamista olisi mahdollista hyödyntää työssä.

Rajala $(1998,240)$ pitää kunnallisen henkilöstön johtamisen kannalta ratkaisevana sitä, millä tavalla henkilöstö toimii organisaatiossa ja miten henkilöstön työsuoritus suhteutuu muiden kanssa. Erityisesti esimiesten tehtävänä on edesauttaa tämänlaisen yhteistyön muodostumista. Yksittäisen henkilön kouluttaminen ei välttämättä käynnistä uutta toimintaa tai ajattelua organisaatiossa, ellei yksilöllinen oppiminen nivoudu kiinteästi muiden toimintaan samassa työyhteisössä tai työprosessissa ja ellei työyhteisössä synny yhteistä ymmärrystä oppimisesta (Docherty 1996, 37). Ristiriitojen ilmeneminen työpaikalla antaa muun muassa aiheen pohtia sitä, missä määrin esimies on oikeasti kiinnostunut henkilöstönsä osaamisesta, sen kehittämisestä ja oppimisen tietoisesta hyödyntämisestä työpaikalla. Tutkimus herättääkin kysymyksen siitä, miten johtamis- ja esimieskoulutusta tulisi kehittää, jotta myös yksittäisten henkilöiden oppimista osattaisiin arvioida työyhteisön toiminnan tuloksellisuuden näkökulmasta. Esimiestaitojen kyvykkyydestä riippuu ratkaisevasti se, miten eri tavoin hankittua ammatillista osaamista ja asiantuntijuutta hyödynnetään työn tuloksellisuuden parantamisessa.

Henkilöstön kehittämisessä koulutustilaisuudet ovat vain yksi keino. Ei ole mitään estettä sille, etteivätkö omaehtoiset opintoryhmät, erilaiset työsidonnaiset verkostot tai työryhmät tai epäviralliset käytäntöyhteisöt (ks. Wenger 1998, 4-6) voisi soveltua myös henkilöstöstrategiaa tukevaksi henkilöstön ja työn kehittymisen väyläksi. Se edellyttää kuitenkin sitä, että esimies näkee näiden kytkennän toiminnan tuloksellisuuteen. Esimiehellä on oltava kykyä nähdä nämä oppimisympäristöt sellaisina, joista voi odottaa kehittämisideoita työpaikalle. Tämä voi toteutua kannustamalla työntekijöitä perustamaan omaehtoisia oppimisryhmiä, ehdottamalla niihin opiskeluaiheita, auttamalla ryhmien kokoontu- misjärjestelyissä, rohkaisemalla työntekijöitä esittelemään opiskeluaiheitaan, työryhmien tai verkostojen asioita työpaikan yhteisissä tilaisuuksissa ja käynnistämällä niistä reflektiivistä diskurssia työpaikan näkökulmasta.

\section{Ryhmäopiskelu ammattiliiton edunvalvonnan edistäjänä}

Ammattiliiton panostaminen jäsentensä omaehtoisen ammatillisen kehittymisen tukemiseen lähtee siitä oletuksesta, että vahvan ammatillisen toimijan on helpompi kohdata muutoksia työpaikalla ja hallita niitä. Ammattiliiton näkökulmasta ryhmäopiskelu edisti jäsenten edunvalvontaa kahdella tavalla. Ensinnäkin se vahvisti ammattiosaamista ja ammatti-identiteettiä ja antoi dialogisia valmiuksia. Toiseksi se aktivoi jäsenten kiinnostusta oman työn ja työpaikan kysymyksiin. He ryhtyivät ottamaan selvää asioista, osallistumaan ja käynnistämään keskusteluja asiakkaiden, työtovereiden ja lähiesimiesten, jopa poliittisten päättäjien kanssa. Ryhmien jäsenet kertoivat myös rohkaistuneen osallistua työpaikkakokousten keskusteluihin aikaisempaa herkemmin. Oppimisen tuloksena lisääntyi työntekijöiden käynnistämä välitön yhteistoiminta työpaikalla.

Tutkimus toi esille myös ryhmäopiskelun kehittämisen kohteita ammattiliiton toiminnassa. Tällaisiksi nousivat muun muassa tukihenkilötoiminnan vakiinnuttaminen, reflektiivisen kirjoittamisen tukeminen sekä ryhmäopiskelun toteuttaminen siten, että se osaltaan tukee ammattiryhmien välistä yhteistyötä työpaikalla.

Erityisenä kehittämisen kohteena nousi opintoryhmien ja paikallisen ammattiyhdistyksen vuoropuhelun rakentaminen niin, että ryhmät oppivat käyttämään tarvittaessa myös edustuksellisen yhteistoiminnan väylää eli omaa yhdistystä. Tiiviimpi dialogi ja toiminnallinen yhteistyö olisivat luontevia ainakin niissä ryhmäopiskelutilanteissa, joissa ryhmä kohtaa opiskelussaan edunvalvontaan liittyviä ongelmia, kuten esimerkiksi uhkaa työpaikan menetyksestä ja työtehtävien oleellisesta muuttumisesta.

\section{Lähteet}

Berndtson, T.(2002). Tietotekniikka työssä, mutta kenen ehdoilla ? Kysely vähän työssään 
tietokonetta käyttäville KTV:läisille ammattiryhmille. Työelämän kehittämisosasto B1/ 2002. Helsinki: Kunta-alan ammattiliitto KTV.

Blom, R., Melin, H. \& Pyöriä, P. (2001). Tietotyö ja työelämän muutos. Palkkatyön arki tietoyhteiskunnassa. Gaudeamus/ Hanki ja Jää-sarja.

Docherty, P. (1996). Läroriket-vägar och värval i en lärande organisation. Stockholm: Arbetslivsinstitutet.

Lash, S. (1995) Refleksiivisyys ja sen vastinparit: rakenne, estetiikka, yhteisö. Teoksessa Bech, U., Giddens, A\& Lash. S. Nykyajan jäljillä-refleksiivinen modernisaatio. Vastapaino.

Linnakylä, P., Malin, A., Blomqvist, I. \& Sulkunen, S. (2000). Lukutaito työssä ja arjessa. Aikuisten kansainvälinen lukutaitotutkimus Suomessa. Koulutuksen tutkimuslaitos. Jyväskylän yliopisto.

Macrorie, K. (1987) Introduction. Teoksessa Fulwiler, T. (ed). The Journal Book. Portsmouth. Heinemann: Boynton/Cook publishers, $1-8$.

Mezirow, J.(1991a) Preface. In Mezirow, J. and Associates: Fostering critical reflection in adulthood. A Guide to Transformative and Emancipatory Learning. San Francisco: Jossey-Bass 1991, xiii-xxi

Mezirow, J.(1991b). Transformative dimensions of adult education. San Francisco: JosseyBass.

Mezirow, J.(1991c) Conclusion: Towards Transformative Learning and Emancipatory Education. In Mezirow, J. and Associates. Fostering critical reflection in adulthood. A Guide to Transformative and Emancipatory Learning. San Francisco: Jossey-Bass, 354-376.

Negt, O. (1971). Soziologische Phantasie und Exemplarisches Lernen. Zur Theorie den Arbeiterbildung. Frankfurt a.M.- Köln: EVA.

Negt, O. (1976). Keine Demokratie ohne Sozialismus. Uber Zusammenhang von Politik, Geschichte und moral. Frankfurt a.M: Suhrkamp.

OECD. (2003). Literacy Skills for the World of Tomorrow. Further Results from PISA2000. http://www.pisa.oecd.org/.
Rajala, T. (1998). Henkilöstö kunnan voimavarana. Teoksessa P. Hoikka (toim.) Kunnat 2000-luvun kynnyksellä: näkökulmia kunnallisalan tutkimukseen ja käytäntöihin. Tampereen yliopisto, 219-249.

Suomi (o)saa lukea. (2000). Tietoyhteiskunnan lukutaidot - työryhmän linjauksia. Opetusministeriö. Opetusministeriön työryhmien muistioita 4:2000.

Wenger, E. (1998). Communities of Practice. Learning, Meaning and Identity. Cambridge University Press.

KM Taina Tuomen väitöskirja "Omaehtoinen ryhmäopiskelu ja ammatillinen kehittyminen. Tutkimus kuntatyöntekijöiden opiskelusta ja ammattiliiton ohjauksellisesta tuesta" tarkastettiin 19.8.2005 Tampereen yliopistossa. Vastaväittäjänä oli professori Anja Heikkinen Jyväskylän yliopistosta. 